\title{
Notes on the Littoral Polychæta of Torquay (Part III).
}

$\mathrm{By}$

\author{
Major E. V. Elwes.
}

\section{Aphroditidæ.}

A synopsis of the Aphroditidæ of the English Channel by $\mathrm{Mr}$. T. V. Hodgson is given in the Journal Marine Biological Association, Vol. VI, No. 2, 1900.

Aphrodita aculeata, Lin. MeIntosh, Mon. Brit. Ann., Vol. II, p. 247.

This species is sometimes found in some numbers, thrown up on the shore after heavy weather, especially at Anstey Cove and Tor Abbey Sands. It is recognized by the fishermen as a "curiosity."

Lepidonotus squamatus, Lin. McIntosh, Mon. Brit. Ann., Vol. II, p. 274.

Only two or three examples found under stones on Babbacombe beach.

Lepidonotus clava, Mont. McIntosh, Mon. Brit. Ann., Vol. II, p. 280.

Occasionally found on all the beaches. Numerous specimens were found on a large buoy in Torquay Harbour.

Lagisca floccosa, Sav. McIntosh, Mon. Brit. Ann., Vol. II, p. 298.

Fairly common under stones.

Lagisca extenuata, Gr. McIntosh, Mon. Brit. Ann., Vol. II, p. 307. Hornell, Fauna of Liverpool Bay, 1892, p. 136, Pl. XIII, Fig. 8.

Very common in roots of Laminaria and under stones. The scales have the groups of papillæ surrounded by lines as represented by Hornell.

Evarne impar, Johnst. McIntosh, Mon. Brit. Ann., Vol. II, p. 358.

Rare. Recorded by Gosse from Anstey's Cove.

Harmothöe spinifera, Ehlers. McIntosh, Mon. Brit. Ann., Vol II, p. 327.

One example only. 
Halosydna gelatinosa, M. Sars. McIntosh, Mon. Brit. Ann., Vol. II, p. 384.

One specimen under a stone on Babbacombe beach.

Polynoe scolopendrina, Sav. MeIntosh, Mon. Brit. Ann., Vol. II, p. 389.

Not uncommon at Corbyn's Head.

Sthenelais b0A, Johnst. McIntosh, Mon. Brit. Ann., Vol. II, p. 408.

Not uncommon in the sand at Tor Abbey Sands.

Sigalion Mathilde, Aud. and Edw. McIntosh, Mon. Brit. Ann., Vol. II, p. 427.

This is the only one of the Torquay Aphroditidæ which has not been also recorded from Plymouth. It is fairly common in the sand at Tor Abbey Sands and Livermead.

-Pholö minuta, O. Fabricius. MeIntosh, Mon. Brit. Ann., Vol. II, p. 437.

The most numerous of all the Torquay Aphroditidæ, inhabiting especially the Laminaria roots.

\section{Glyceridæ.}

Glycera convoluta, Kef. De St. Joseph, Ann. Sci. Nat. Zool., Vol. XVII, 1894 , p. 27.

Fairly numerous in Tor Abbey Sands and at Livermead.

Glycera Lapidum, Qfg. McIntosh, "On the British Glyceridæ," Ann. Nat. Hist., S. 7, Vol. XV, p. 39, 1905.

One specimen in the inner harbour of Torquay and one on the Babbacombe beach.

\section{Eunicidæ.}

This family is represented at Torquay by five littoral species. For the key to the Eunicidæ of the English Channel the papers by Baron de St. Joseph, entitled "Les Annélides Polychètes des Côtes de Dinard" and "Les Annélides Polychètes des Côtes de France," the "Notes on the British Eunicidæ," by Professor McIntosh, Annals of Natural History, Vol. XI, p. 553, 1903, and the Cambridge Natural History, Völ.'II, havè been consulted.

Lysidice ninetTa, Aud. and Edw. Johnst., Catalogue of Worms, p. 140 .

Small specimens thirty to fifty millimetres in length; extremely common amongst Laminarian roots and limestone rocks. 
Nematonereis uniconnis, Grube. De St. Joseph, Ann. Sci. Nat., V, 1888, p. 207.

Fairly common in the limestone rocks at Babbacombe, but as is the case with the last species it is very rarely perfect.

Staurocephalus rubrovittatus, Grube. De St. Joseph, Ann. Sci. Nat., V, 1888, p. 235.

One specimen obtained at an unusually low spring tide at Corbyn's Head.

Ophryotrocha puerilis, Clpd. and Meczn. Cambridge Nat. Hist., Vol. II, p. 319, Fig. 170.

This little worm is frequently seen on the sides of glass vessels containing roots and pieces of rocks. On one occasion a small aquarium in the museum of the Torquay Natural History Society was found to be swarming with this species.

Lumbriconereis latreilli, Aud. and Edw. De St. Joseph, Ann. Sci. Nat. Zool., V, 1898, p. 276.

Three or four in rather coarse gravel on Babbacombe beach.

\section{Sphœrodoridæ.}

Ephesia Gracilis, Rathke. De St. Joseph, Ann. Sci. Nat.Zool., XVII, 1894, p. 33. McIntosh, Ann. Nat. Sci., S. 8, Vol. II, 1908, p. 528 and 540.

Two or three from Meadfoot beach.

Ephesia Peripatus, Clpd, nee Johnst. Claparède, Beob. über Anat. und Ent. wirbellosen thiere, p. 50, de St. Joseph, Ann. Sci. Nat. Zool., XVII, 1894, p. 41.

Two specimens from Corbyn's Head. According to de St. Joseph this species differs from $\boldsymbol{E}$. gracilis by several characters, but he only mentions two, viz. the composite bristles and the absence of the "l'éventail de papilles" below the feet which exists in E. gracilis. The bristles of $E$. peripatus of the Torquay examples seem, besides being compound, to be not quite so stout and not so much bulged as those of E. gracilis.

\section{Ariciidæ.}

Aricia latreilli, Aud. and Edw. De St. Joseph, Ann. Sci. Nat. Zool., XVII, 1894, p. 85.

Several examples were dug up from the sand at Tor Abbey Sands. In this species there are about thirty bristle-bearing segments in the anterior region, while in $A$. cuvieri there are only twenty-one. 


\section{Spionidæ.}

In preparing the accompanying key to the Spionidæ of the English Channel Mesnil's paper, entitled "Études de Morphologie externe chez les Annélides" and Professor McIntosh's "Notes on the British Spionidæ," Annals of Nat Hist., S. 8, Vol. III, have been consulted.

Scolecolepis vulgaris, Johnst. McIntosh, Annals of Nat. Hist., S. 8, Vol. III, 1909, p. 159.

At the west end of Tor Abbey Sands; rare.

Scolecolepis fuliginosa, Clpd. MeIntosh, Annals of Nat. Hist., S. 8, Vol. III, 1909, p. 160.

Very numerous at west end of Tor Abbey Sands and at Livermead. In December numbers were found coiled up together under stones.

Nerine cirratulus, Delle Chiaje. McIntosh, Annals of Nat. Hist., S. 8, Vol. III, 1909, p. 158.

Tor Abbey Sands; not numerous.

Aonides oxycephala, Sars. Mesnil, Bull. Sci. France et Belgique, XXIX, 1896, p. 242.

Numerous in rather foul mud under stones at Livermead.

Polydora ciliata, Johnst. McIntosh, Annals of Nat. Hist., S. 8, Vol. III, p. 169.

Very numerous in the small pools in the limestone boulders on the shore.

Polydora flava, Clpd. McIntosh, Annals of Nat. Hist., S. 8, Vol. III, p. 169.

Numerous on rocks and in pools.

Spiopinanes bombyx, Clpd. McIntosh, Annals of Nat. Hist., S. 8, Vol. III, p. 167.

A few specimens at the east end of Tor Abbey Sands. Mesnil remarks that he found this species in company with Echinocardium cordatum; this sea urchin is also common on Tor Abbey Sands.

\section{Magelonidæ.}

Magelona papillicorisis, Fr. Müller. McIntosh, Annals of Nat. Hist., S. 8, Vol. III, p. 174.

One example at a very low spring tide on Tor Abbey Sands.

\section{Ammocharidæ.}

Owenia fusiformis, Delle Chiaje. De St. Joseph, Ann. Sci. Nat. Zool., V, 1898, p. 397. 
The tubes of this species are very numerous on Tor Abbey Sands; they appear to be loose in the sand, not fixed vertically, as is usual with tube-dwelling annelids in sand. They are largest in the middle, tapering towards both ends, made chiefly of small pieces of shell placed edgeways.

\section{Cirratulidæ.}

In the accompanying key to the Cirratulidx of the Channel the classification of Caullery and Mesnil in Les formes epitoques et l'evolution des Cirratuliens is adopted.

Audouinia tentaculata, Montagu. De St. Joseph, Ann. Sci. Nat. Zool., XVII, 1894, p. 49.

Numerous at Meadfoot, Hope's Nose, and Tor Abbey Sands in rather foul mud; young ones about $40 \mathrm{~mm}$. in length appear to live in crevices in rocks.

Dodecaceria concharum, Oersted. Caullery et Mesnil, Annales de l'Université de Lyon, Fasc. XXXIX, 1898, p. 11.

Very numerous in the limestone boulders at Babbacombe.

Heterocirrus viridis, Lang. $=$ H. favoviridis, de St. Joseph. Caullery et Mesnil, Ann. de l'Université de Lyon, Fasc. XXXIX, 1898, p. 117.

Found occasionally in small pools in limestone rocks at Babbacombe.

Heterocirrus caput esocis, de St. Joseph. Caullery et Mesnil, Ann. de l'Université de Lyon, Fasc. XXXIX, 1898, p. 122.

Two or three examples found in the same localities as the last species. I have not seen any British records of these two species of Heterocirrus.

\section{Terebellidæ.}

The accompanying key to the Terebellidæ is founded on the table given by Baron de St. Joseph in "Les Annélides Polychètes des Côtes de Dinard," Ann. Sci. Nat. Zool., XVII, 1894, p. 180.

Polymnia nebulosa, Montagu. De St. Joseph, Ann. Sci. Nat. Zool., XVII, 1894, p. 219.

Occasional specimens at Corbyn's Head and in rocks between Oddicombe and Babbacombe beaches.

Polymnia nesidensis, de St. Joseph. Ann. Sci. Nat. Zool., XVII, 1894, p. 211.

Very common in Laminaria roots, etc.

Lanice conchilega, Pallas. De St. Joseph, Ann. Sci. Nat. Zool., XVII, 1894, p. 211.

Numerous on Tor Abbey Sands, especially at the east end. 
E. V. ELWES.

\section{Ampharetidæ.}

Melinna adriatica, Marenzeller. Sitzb. d. k. Akad. Wiss. zu Wien, LXIX, p. 472.

Two at extreme low water at Livermead amongst Zostera roots.

\section{Maldanidæ.}

Clymene cerstedil (?), Clpd. De St. Joseph, Ann. Sci. Nat. Zool., XVII, 1894, p. 137.

On the east side of Tor Abbey Sands; not common.

Leiochone clypeata, de St. Joseph. Ann. Sci. Nat. Zool., XVII, 1894, p. 139.

Numerous at extreme low water in the centre of Tor Abbey Sands.

\section{Capitellidæ.}

Notomastus latericeus, Sars. De St. Joseph, Ann. Sci. Nat., XVII, 1894, p. 117.

Under stones, Corbyn's Head and Livermead.

\section{Opheliidæ.}

Polyopthalmus pictus, Duj. De St. Joseph, Ann. Sci. Nat. Zool., V, 1898 , p. 385.

Common amongst Corallines, ete., in rock pools.

\section{Arenicolidæ.}

Arenicola marina, L. Gamble, Quart. Journ. Micro. Sci., XLIII, p. 419 .

Common on Tor Abbey Sands.

Arenicola ecaudata, Johnst. Gamble, Quart. Journ. Micro. Sci., XLIII, p. 419.

This species seems to be very different in its habits to A. marina; instead of burrowing in soft mud and sand it lies under stones in gravel at Hope's Nose and Babbacombe beach.

\section{Chlorhœmidæ.}

Siphonostoma affinis, M. Sars. De St. Joseph, Ann. Sci. Nat. Zool., XVII, 1894 , p. 96.

Under stones at Corbyn's Head.

\section{Sabellidæ.}

The accompanying key to the Sabellids of the English Channel is founded on the table given by Baron de St. Joseph in "Les Annélides 
Polychètes des Côtes de Dinard," Ann. Sci. Nat. Zool., XVII, 1894, p. 248.

Sabella pavonina, Sav. De St. Joseph, Ann. Sci. Nat. Zool., XVII, 1894, p. 267.

I was somewhat surprised to find several examples of this large worm in the inner harbour at Torquay only a few yards from the "Strand." They were living in mud and gravel which could hardly be called clean.

Potamilla reniformis, O. F. Müller. Soulier, Revision des Annélides de la region de Cette, p. 120 , Fig. 4.

This species is found on the sides of the cave under the men's bathing-place at Petit Tor. This is the cave mentioned by Gosse in the British Sea Anemones and Corals, where he found the sea anemones Halcampa microps and Edwardsia carnea.

Potamilla torelli, Mgr. De St. Joseph, Ann. Sci. Nat. Zool., XVII, 1894, p. 296.

Common in the small rock pools in the limestone rocks between Oddicombe and Babbacombe beaches.

Fabricia sabella, Ehr. De St. Joseph, Ann. Sci. Nat. Zool., XVII, 1894, p. 319.

A little Sabellid which appears to be referable to this species is very common in the little pools in the rocks at Babbacombe, in company with the last species, Polydora and Dodecaceria. It lives in small holes in the rocks, with a tube of mud projecting a little from the opening.

Oria ARMandi, Clpd. Soulier, Revision des Annélides de la region de Cette, 1902, p. 114, Fig. 2.

One specimen from Babbacombe rock pools. As de St. Joseph remarks, the eyes in this species quickly disappear, while in $F$. sabella they are persistent even in Balsam preparations. I have also obtained this species at Newquay, Cornwall.

Jasmaneira elegans, de St. Joseph. Ann. Sci. Nat. Zool., XVII, 1894, p. 316.

Found occasionally crawling up the sides of glass vessels containing roots of Laminaria and pieces of limestone rock. It was first recorded as a British species by Miss Newbiggin in 1900 .

Amphiglena mediterranea, Clpd. Soulier, Revision des Annélides de la region de Cette, p. 109, Fig. 1.

Found under the same conditions as the last species. 


\section{Serpulidæ.}

In preparing the key to the Serpulids of the English Channel the table given by Baron de St. Joseph in the Annales des Sciences naturelles Zool., XVII, 1894, p. 259, and, for the genus Spirorbis, the papers by Caullery and Mesnil, "Études sur la morphologie, etc., chez les Spirorbes," have been consulted.

Serpula vermicularis, Lin. De St. Joseph, Ann. Sci. Nat. Zool., XVII, 1894, p. 328.

On shells thrown up on the shore at Tor Abbey Sands.

Pomatoceros triqueter, Lin. De St. Joseph, Ann. Sci. Nat. Zool., XVII, 1894, p. 353.

Extremely common on stones.

Hydroides norvegica, Zunn. De St. Joseph, Ann. Sci. Nat. Zool., V, 1898, p. 440.

On a stone at Petit Tor beach; numerous on buoys in Torquay Harbour.

Spirorbis borealis, Daudin. Caullery et Mesnil, Bull. Scien. de la France et de la Belgique, XXX, 1897, p. 211.

Very common on Fucus.

Spirorbis spirillum, Lin.=lucidus, Mont. Caullery et Mesnil, Bull. Scien. de la France et de la Belgique, XXX, 1897, p. 198.

On Sertularia abietina thrown up on the shore.

\section{Hermellidæ.}

Sabellaria alveolata, Linn. Cambridge Nat. Hist., Vol. II, Figs. 131 and 135 .

Very common all along the Torquay coast. 


\section{KEY TO THE GENERA OF THE EUNICIDA FOUND ON THE FRENCH AND ENGLISH COASTS}

Four tentacles.

Two frontal palps simu-

Five prostomial
tentacles. $\left\{\begin{array}{c}\left.\begin{array}{c}\text { Two frontal palps simu- } \\ \text { lating stunted tentacles } \\ \text { arising from the an- } \\ \text { terior border of the } \\ \text { prostomium. } \\ \text { No frontal palps } \\ \text { as above. }\end{array}\right\} \begin{array}{l}\text { Two tentacular cirri on the second segment. } \\ \text { No tentacular cirri on the second segment }\end{array} \quad \begin{array}{l}\text { Two tentacular cirri on the second segment } \\ \text { No tentacular cirri on the second segment }\end{array} \text { Four tentacles. } \\ \text { Two dorsal and two ventral tentacles }\end{array}\right.$

OnUPHIs, Aud. and Edw.

Hyalingeta, Mgr.

Eunice, Cuv.

Three tentacles. $\{$ Branchiæ present, consisting of one filament

No branchiæ

$\{$ Palps long. Denticles of upper jaw numerous, more than thirty. Feet with two $\}$

Two tentacles. branches

MaRPHYSA, Qfg.

OpHRYotrocha, Clpd.

AMPHIRO, Kbg.

One tentacle.

No branchix

Lysidice, Sav.

(Compound bristles with toothed terminal pieces or simple hooked crotchets or both)

in some at least of the feet, in addition to simple winged capillary bristles $\quad$.$\} LUMBRIConereis, Blv.$

Staurocephalus, Gr. winged Mandibles small or absent, the three anterior pairs of denticles con- $\}$ DrILONERers, Clpd.

capillary $\left\{\begin{array}{r}\text { sisting of simple hooks } \\ \text { Mandibles massive, the three anterior pairs of denticles consisting of }\end{array}\right.$

bristles toothed plates, or of one pair of hoos and two pairs of toothed

only.

plates

Arabella, Gr. 
Genus Ondphis.

Tentacular cirri arise from the anterior border of the second segment. Tube flattened, made of small stones and shells

\section{Genus Hyalingscis.}

Branchiæ commence 23-26th foot. Tube translucent, quill-like. L., $100 \mathrm{~mm}$.

Branchiæ commence on 4 th segment. Brown bands on dorsum permanent in spirit. Tube of small shells and stones. L., $60 \mathrm{~mm}$.

\section{Genus Eunice.}

Body with numerous olive brown bands and spots, speckled with white. Maximum number of filaments of branchiæ, sixteen. L., $120 \mathrm{~mm}$

Three reddish bands on the back of each segment. Maximum number of filaments of branchiæ, five, on the 30 th foot. L., $60 \mathrm{~mm}$.

\section{Genus Marphysa.}

Branchiæ commence on 21st foot, filaments of branchiæ, arising from nearly the same spot, forming a tuft. Maximum number of filaments, eight. L., 400 to $600 \mathrm{~mm}$.

Branchiæ commence on 14th foot, forming a comb. Maximum number of filaments, about twenty-five. L., $160 \mathrm{~mm}$.

Branchiæ consisting of a single filament. L., $15 \mathrm{~mm}$.

Genus Ophryotrocha.

Small form. Segments with a girdle of cilia. L., $4 \mathrm{~mm}$.

\section{Genus AmpHiro.}

Four eyes. Branchiæ commence on 16th segment. L., $9 \mathrm{~mm}$. Aud. and Edw.

\section{M. sanguinea, Montagu.}

\section{Bellii, Aud. and Edw.} M.* fallax, Mar, and Bohr.

O. puerilis, Clpd. and Meczn.

$A$.* Johnstoni, Lang.

Genus Lysidice.

Head broad, flattened, with a median notch; tentacles short. Red spotted with white, the 4 th segment entirely white. L., $100 \mathrm{~mm}$. 


\section{KEY TO SPECIES OF EUNICIDA-continued.}

\section{Genus Staurocephalus.}

Palps earlike, not jointed. Back with brilliant red bands, L, $20 \mathrm{~mm}$.

Palps and tentacles jointed. Body colourless, covered with small glands, 4 eyes. L., $18 \mathrm{~mm}$.

Palps and tentacles jointed. Body colourless, no small glands, 2 eyes. L., $15 \mathrm{~mm}$.

S. rubrovittatus, $\mathrm{Gr}$

S. ciliatus, Kef.

- S. pallidus, Lang.

Genus Nematonereis.

Body greyish, very narrow, $1 \mathrm{~mm} .2$ eyes with short subulate tentacle arising between them. L., $200 \mathrm{~mm}$.

Genus Lumbriconereis.

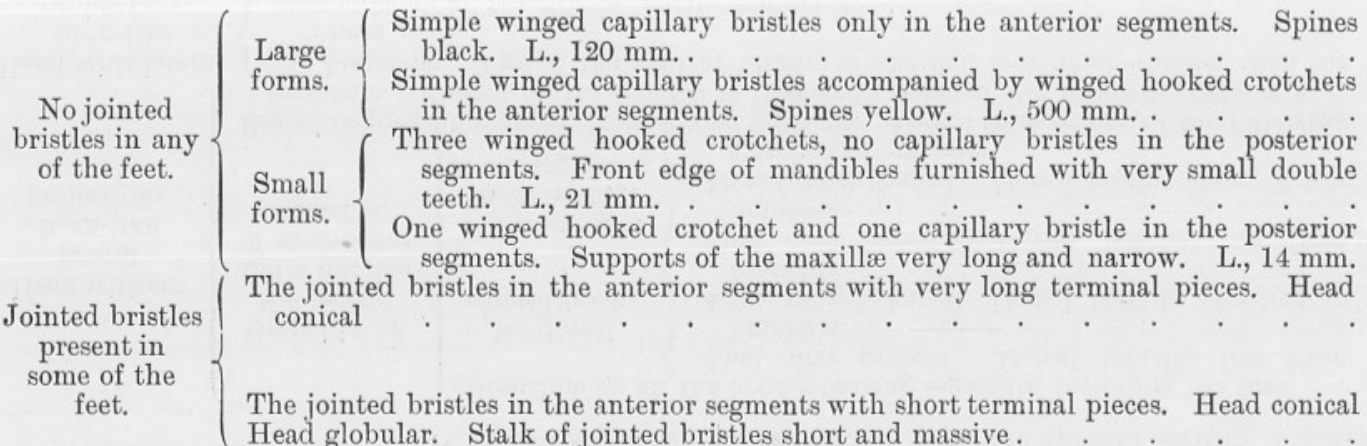

Genus Drilonereis,

Upper dental apparatus with five pairs of jaws. Left maxilla with several small teeth at the base. L., $20 \mathrm{~mm}$.

Upper dental apparatus with four pairs of jaws. Left maxilla not toothed at the base. $\dot{\mathrm{L}} ., 90 \mathrm{~mm}$

\section{Genus Arabelia.}

Upper dental apparatus with five pairs of jaws. Lower part of the maxillæ with numerous small teeth. L., 250 to $450 \mathrm{~mm}$.

* Not yet recorded from the British area.
D.* macrocephala, de St. Joseph.

D.* filum, Clpd.

N, unicornis, $\mathrm{Gr}$

L. fragilis, O. F. Müller.

L. impatiens, Clpd.

L.* labrofimbriata, de St. Joseph.

$L$.* paradoxa, de St. Joseph.

L. Latreilli, Aud and Edw $=N a r$ donis, Gr. = Edwardsi, Clpd. =tingens, Kef

L. gracilis, Ehlers.

L.* coccinea, Ren.

A. iricolor, Montagu $=$ Maclovia gigantea, $\mathrm{Gr}$.
西 


\section{KEY TO THE GENERA OF SPIONIDE FOUND ON THE FRENCH AND ENGLISH COASTS OF THE CHANNEL.}

A. Fifth segment not enlarged, without special strong bristles.

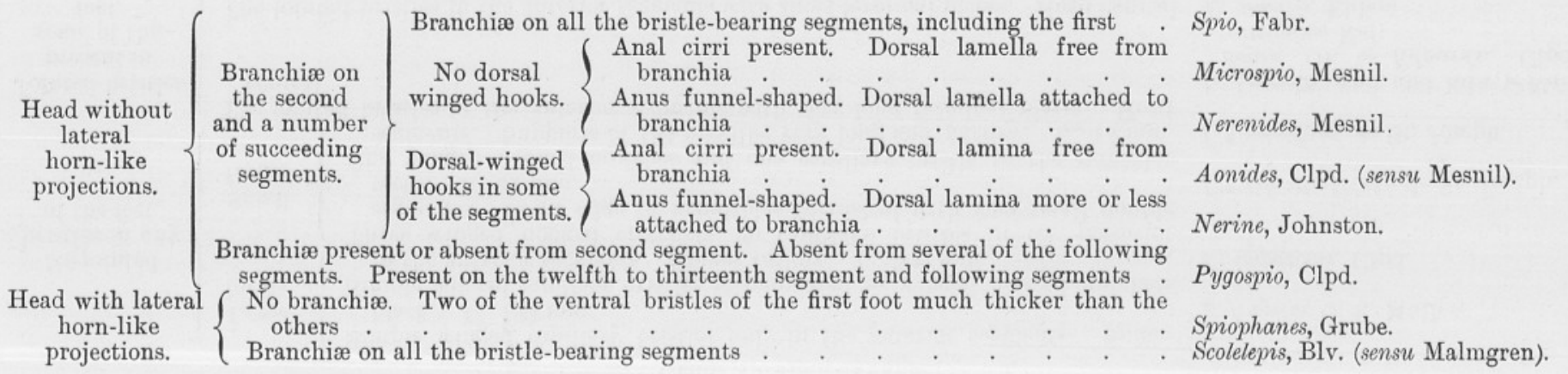

B. Fifth segment enlarged, furnished with special strong bristles.

Branchiæ commence on the second segment No branchiæ before the sixth segment 


\section{KEY TO THE SPECIES OF SPIONID AE FOUND ON THE FRENCH AND ENGLISH COASTS \\ OF THE CHANNEL.}

Genus SpIo.

Prostomium rounded in front, usually four eyes, winged crotchets with two points commence at thirteenth to fifteenth segment. Anal cirri, four. L., $30 \mathrm{~mm}$.

\section{Genus Microspio.}

S. martinensis, Mesnil. =filicornis, Fabr. (?).

Prostomium terminated by two rounded bosses, eyes four, anal cirri four. Winged crotchets commence ventrally on eighth foot. L., $10 \mathrm{~mm}$. .

\section{Genus Nerenides,}

Prostomium very pointed, four eyes, lamella as long as and joined to branchia. Winged crotchets with two points. L., 70 to $100 \mathrm{~mm}$.

Genus Aonides,

Prostomium pointed, four eyes in a line. About twenty pairs of branchiæ. Eight anal cirri. Winged crotchets with two points. L., $80 \mathrm{~mm}$

\section{Genus Nerine.}

Winged (Dorsal lamella longer than and completely attached to the branchia in the first

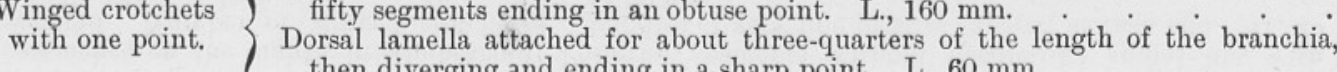
then diverging and ending in a sharp point. L., $60 \mathrm{~mm}$. .

Winged crotchets with two points. Head terminating in a sharp point ; colour green, L. $70 \mathrm{~mm}$. .

Genus Pygospio.

Branchiæ on second bristled segment present. Stalks of winged crotchets without a distinct swelling. L., $10 \mathrm{~mm}$. .

No branchiæ on second segment. Stalks with a distinct swelling. L., $10 \mathrm{~mm}$.

Genus Scolelepis.

Winged crotchets with three points. L., $180 \mathrm{~mm}$.

Winged crotchets with two points. Head and back marked with black pigment. L., $75 \mathrm{~mm}$.

* Not yet recorded from the British area. 
Genus Spiophanes, Gr.

Tube dweller. Number of winged crotchets, eleven to fourteen. Anal cirri, two. L., $50 \mathrm{~mm}$. . . S. bombyx, Clpd.

\section{Genus Polydora.}

Abnormal bristles of fifth segment with a comb-like fibrous crest. Dorsal bristles present on first segment. $\} * P$. Caulleryi, Mesnil.
Branchiæ commence on seventh bristle-bearing segment. L., $8 \mathrm{~mm}$.

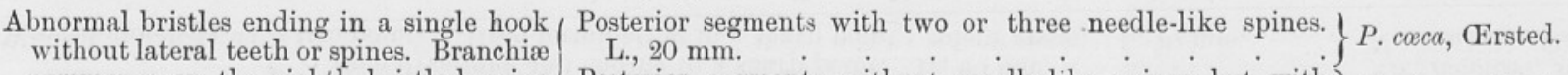
commence on the eighth bristle-bearing segment. Number of winged crotchets usually three or four

Posterior segments without needle-like spines but with bundles of very fine bristles tapered at each end. L., 20 . flava, Clpd. = pusilla, de St. to $50 \mathrm{~mm}$.

$$
\left.\begin{array}{l}
\text { Stem of winged crot- } \\
\text { chets with a bulge. } \\
\text { Branchiæ commence } \\
\text { on seventh segment. } \\
\text { Number of winged } \\
\text { crotchets u sually } \\
\text { eight }
\end{array}\right\}
$$

bnormal bristle with lateral teeth or projections in addition

to main hook.

Stem of winged crot-
Posterior segments with large dorsal bristles terminating in

Posterior h. $50 \mathrm{~mm}$. more or less black pigment. L., $20 \mathrm{~mm}$..$\}$. ciliata, Johnst. chets withouta bulge. Number of crotchets from three to five

Branchiæ commence on the eighth bristle-bearing segment.

Abnormal bristles ending in a truncated tip with nearly $P$. quadrilobata, Jac.

equal teeth, sometimes with a brush of fibres. L., 10 to

Branchiæ commence on tenth segment. Abnormal bristles with a small tooth on concave side. L., $8 \mathrm{~mm}$.
Branchiæ commence on seventh segment. Abnormal bristles

Branchiæ commence on seventh segment. Abnormal bristles with a kind of hood on convex side, wings of hood forming two unequal points on the concave side. L., $5 \mathrm{~mm}$. . *P. Giardi, Mesnil. P. armata, Lang.

\section{Genus Boccardia.}

Fifth segment with two different kinds of large bristles. L., $15 \mathrm{~mm}$.

\footnotetext{
* Not yet recorded from the British area.
} 


\section{KEY TO THE GENERA AND SPECIES OF THE CIRRATULID $A$ FOUND ON THE FRENCH AND ENGLISH}

COASTS OF THE CHANNEL.

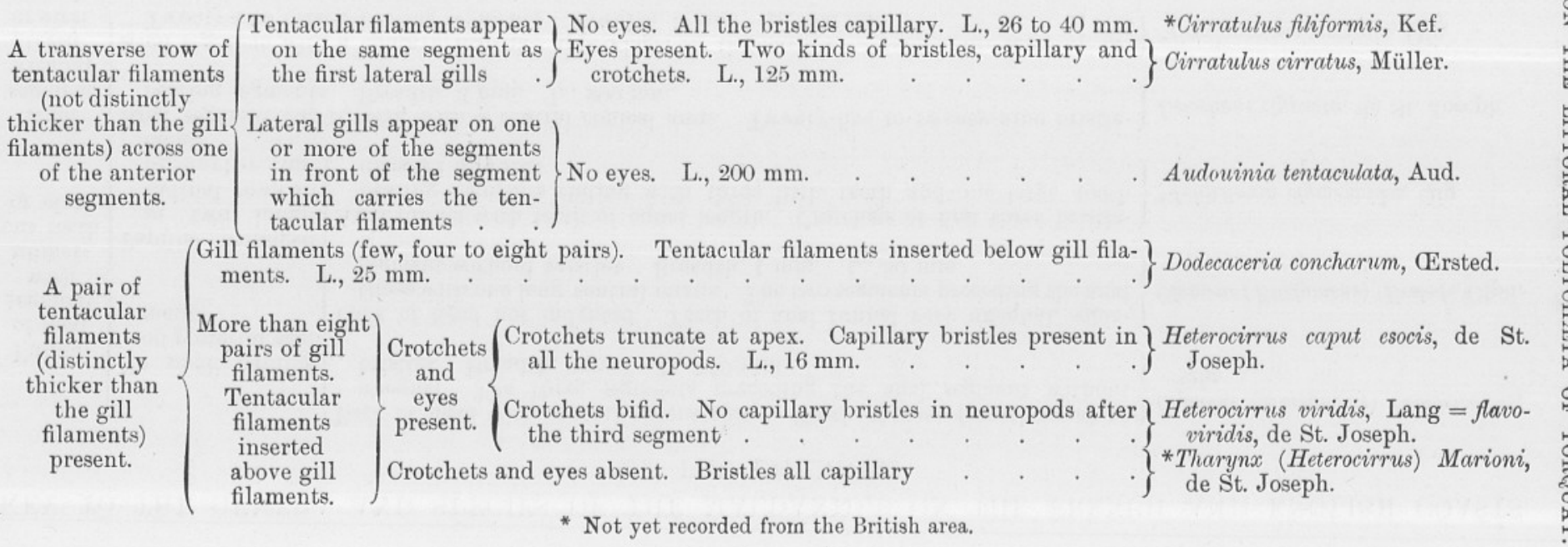

* Not yet recorded from the British area. 


\section{KEY TO THE GENERA AND SPECIES OF THE MALDANIDA ON THE FRENCH AND ENGLISH COASTS OF THE CHANNEL.}

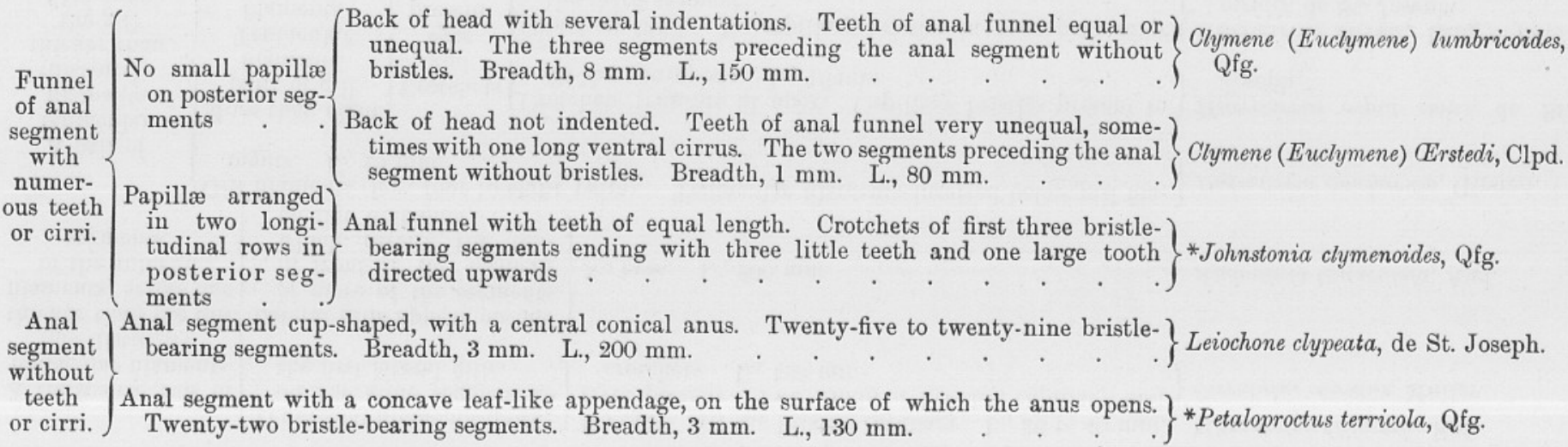

* Not yet recorded from the British area. 
KEY TO THE SPECIES OF TEREBELLIDA FOUND ON THE FRENCH AND ENGLISH COASTS

OF THE CHANNEL.

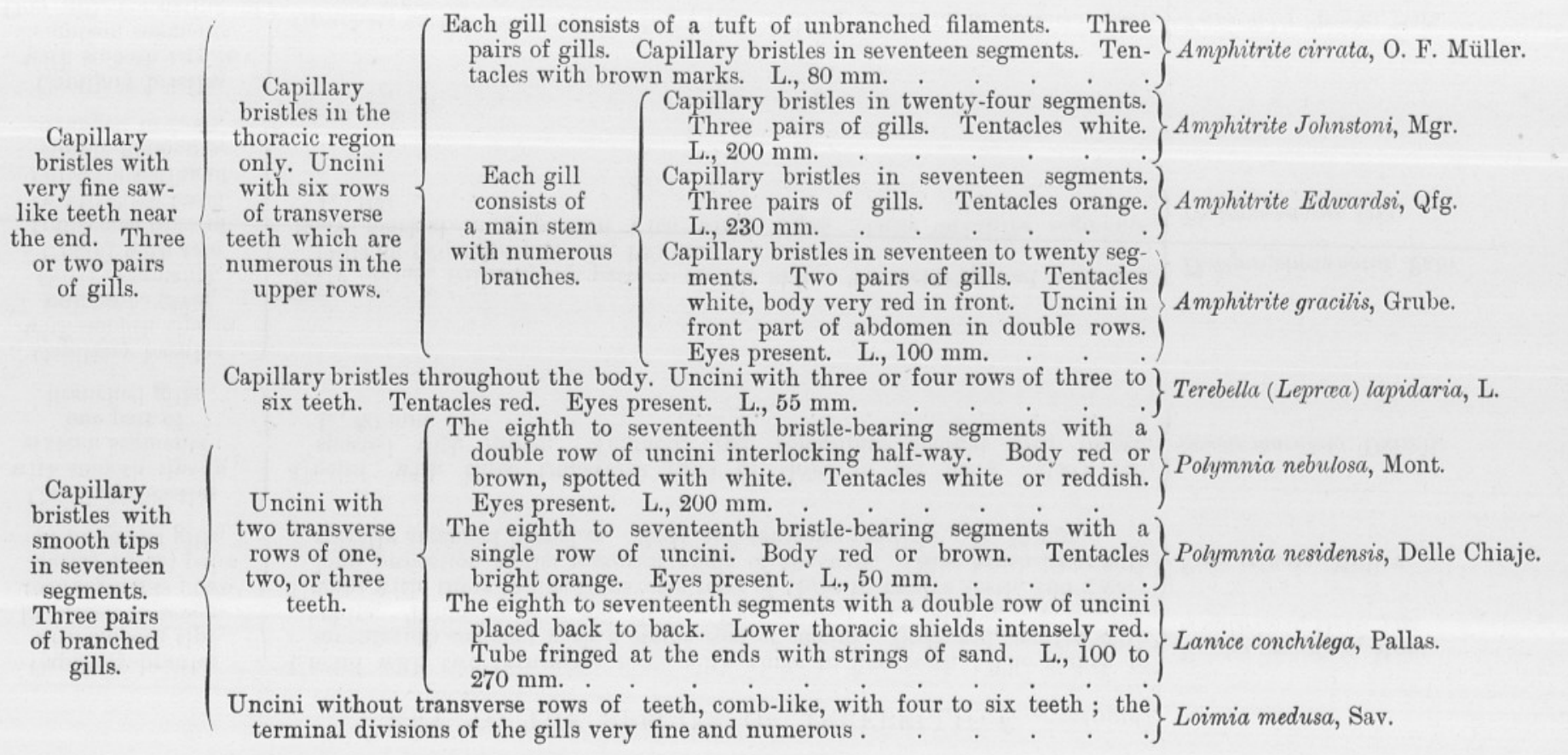

terminal divisions of the gills very fine and numerous. 


\section{KEY TO THE SPECIES OF TEREBELLIDA-continued.}

Capillary bristles with smooth tips in fifteen to seventeen segments ; two (rarely three) pair of branched gills.

Capillary bristles with smooth tips in sixteen segments ;

one pair of branched gills.

Capillary bristles with smooth tips in numerous (over

thirty) segments.

Uncini with two transverse rows of two to three teeth.

Gills, consisting of simple filaments, arranged in rows.

Capillary bristles with smooth tips in eighteen segments.

One gill, consisting of

four comb-like plates arising from a single peduncle.
Uncini with two transverse rows, with three to five teeth. The eighth to seventeenth segment with a single row of uncini. Body red, spotted with Nicolea venustula, Mont. white. Tentacles dark red, short. Eyes present. L., $50 \mathrm{~mm}$. . ${ }^{\prime} .=$ zostericola, Oerst. (?),

Uncini with three to five transverse rows of three to twelve teeth, and a very long projection at the posterior angle of the base. Gills brush-like, with Pista cristata, Müller. spirally arranged branches. Body and tentacles reddish. L., $75 \mathrm{~mm}$.

Uncini with three transverse rows of three to six teeth. Body red, spotted with brown. Tentacles red, sometimes spotted with brown. Scione maculata, Dalzell. L., $60 \mathrm{~mm}$.

Body orange, without any pattern on the skin. Tentacles spotted with red. ? Gills on two segments. L., $120 \mathrm{~mm}$.

Thelepus cincinnatus, Fabr. Body marked in a pattern with white lines. Gills on three segments. $\}$ Thelepus setosus, Qfg. Crotchets with a long stalk in front part of body. Uncini, in posterior part, $\}$ Terebellides Stroemi, Sars.
comb-like. L., $60 \mathrm{~mm}$. 
Capillary bristles with smooth tips in fifteen segments. Gills, three pairs, each gill consist-

Crotchets with a long stalk in front part of body. Uncini in posterior part.
Body orange. Tentacles violet. L., $30 \mathrm{~mm}$. ing of a single filament.

Number of segments with capillary bristles about twenty-eight to sixty. Uncini appear at ninth bristle-bearing segment. Six pairs $\}$ Polycirrus caliendrum, Clpd. of nephridia. L., 30 to $100 \mathrm{~mm}$.

smooth. None of

\begin{tabular}{c|c} 
No & them winged. \\
Body and tentacles
\end{tabular} Number of segments with capillary bristles about twenty-eight to orange. forty. Uncini appear at seventh to ninth bristle-bearing segment. smooth. Some of them slightly winged.
Capillary bristles $f$ Colourless, or very slightly tinged with yellow. Number of segments,

Three pairs of nephridia. L., 80 to $100 \mathrm{~mm}$. . Conspicuous red blood. No uncini in the first twelve bristle-bearing Entirely colourless. Uncini appear at the seventh to tenth bristledenticulated. with capillary bristles, about fifteen.

* Not yet recorded from the British area. 


\section{KEY TO THE GENERA AND SPECIES OF THE SABELLIDA FOUND ON THE FRENCH AND ENGLISH} COASTS OF THE CHANNEL.

A. Ventral bristles of the thorax of two different kinds, namely simple winged capillary bristles and uncini.

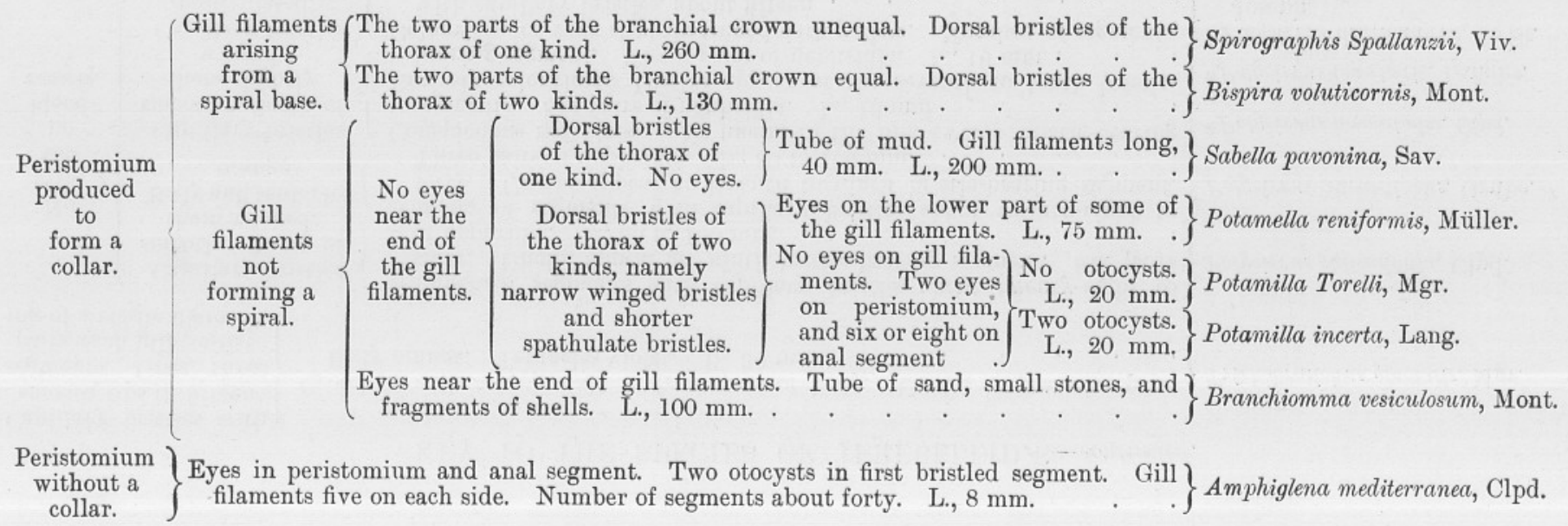




\section{KEY TO THE GENERA AND SPECIES OF THE SABELLIDA-continued.}

B. Ventral bristles of the thorax of one kind, namely, either uncini or crotchets with a long stalk.

$\left.\begin{array}{c}\text { Ventral bristles of } \\ \text { thorax uncini. }\end{array}\right\} \begin{gathered}\text { Each gill filament carries a number of eyes. Two clublike dorsal appendages arise } \\ \text { from near each pair of eyes. }\end{gathered}$ Dasychone bombyx, Dalyell.

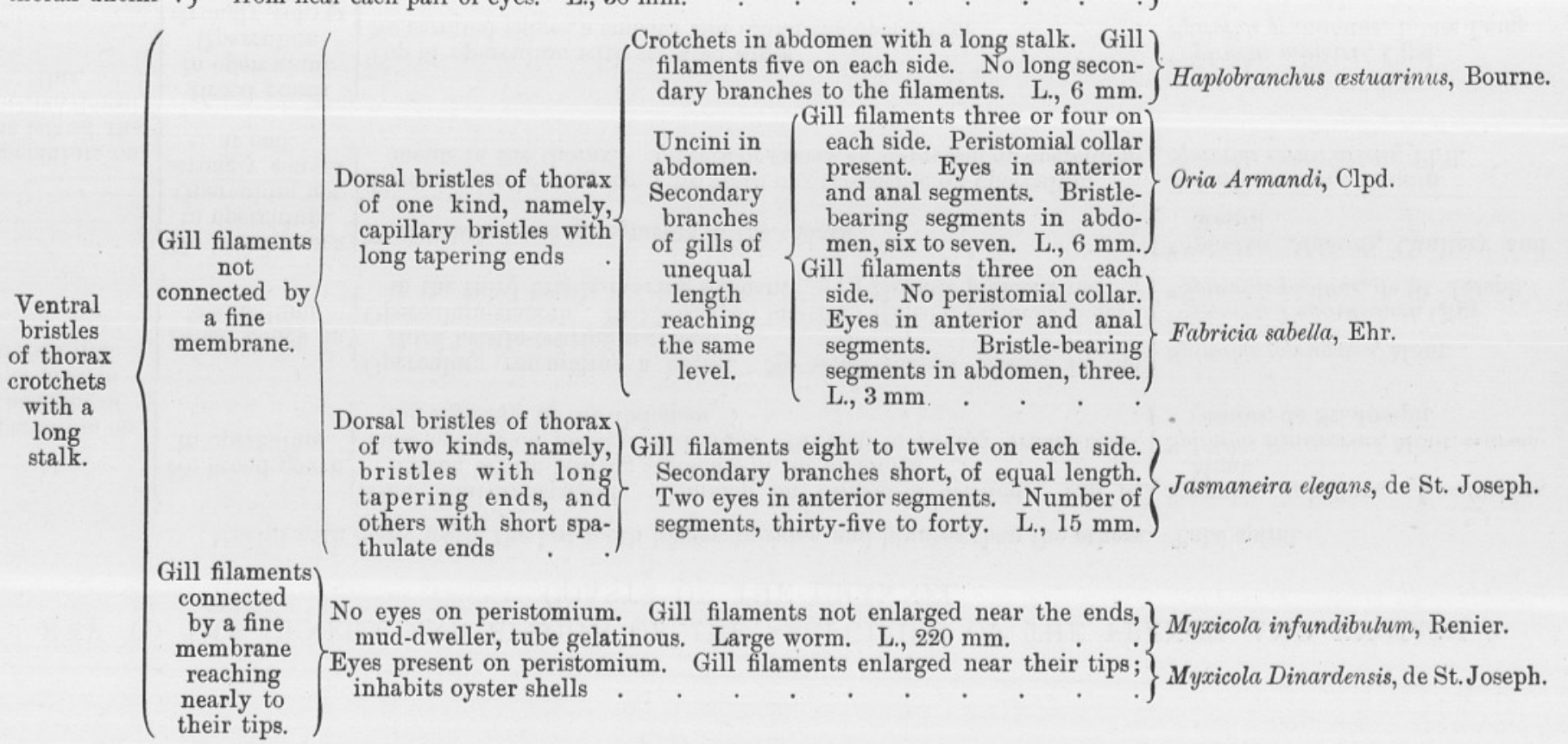


KEY TO THE GENERA AND SPECIES OF THE SERPULIDA OF THE FRENCH AND ENGLISH COASTS OF THE CHANNEL.

Uncini with many teeth, the last tooth longer, broader, and blunter than the others. Tube spiral.

Operculum on the right of the median dorsal line.

Operculum on the left of the median dorsal line.

(Tube semi-transparent. Common on Sertularia abietina. Ten to Spirorbis spirillum, L.=lucidus, No brood pouch sixteen bristle-bearing segments in the abdomen . . . . Mont.

in operculum. Tube opaque on lobsters and crabs. Sixteen to twenty bristle-bear- Spirorbis sinistrorsus, Mont. $=$ armoing segments in the abdomen . . . . . . . . . ricanus, de St. Joseph.

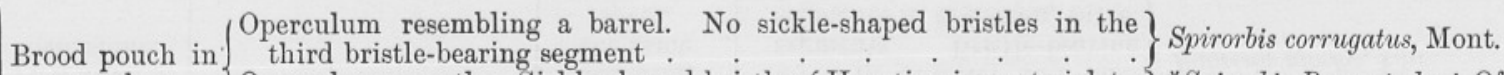

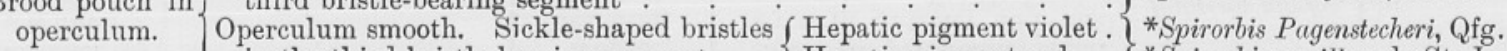

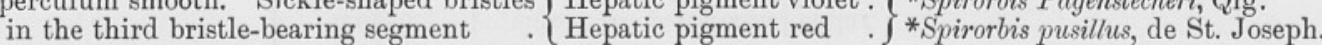
at end.

Three bristle-bearing seg- $\{$ No teeth or excrescence on operculum . Spirorbis borealis, Daudin.

Brood pouch in operculum. Operculum
strongly convex No serrated ridges, a smooth rim round the operculum Top of operculum with serrated edges Spirorbis granulatus, L. nec Lang. 


\section{KEY TO THE GENERA AND SPECIES OF THE SERPULIDE-continued.}

Uncini deeply hollowed out at
back with very numerous and L, without gills, 20 to $45 \mathrm{~mm}$. . . . . . . . . Protula tubularia, Mont. very small teeth, terminated

幺 by a stout spine. Tube not spiral

Operculum globular, transparent. Some sickle-shaped bristles with

winged stalks present in thor

L., 8 to 15 mm

Apomatus similis, Mar. and Bohr.

Uncini with about fourteen teeth, last tooth broader, blunter, and larger than the Two opercula at the end of stems with secondary branches. Ends of
gills not enlarged. L., $5 \mathrm{~mm}$. Filograna implexa, Oken. others. Tubes very slender, intertwining

Uncini with eight or nine teeth, (Tube adherent usually with three ridges, the centre ridge projecting in ) the last tooth hollowed out a sharp tooth over the orifice. Operculum with two projections on the Pomatoceros triqueter, L. underneath like a gouge stem, flat at the top or conical, with or without one to three spines. .

Uncini with five to seven teeth, Operculum funnel-shaped, margin crenate. Gills about thirty on each the last tooth stronger than side. Number of teeth in uncini of thorax five. L., 20 to $50 \mathrm{~mm}$. . 5 the others, but pointed like Operculum funnel-shaped with a circle of spines, with thorns on their them pines arising from the centre. "Number of teeth in uncini of thorax Hydroides norwegica, Gunn. 